DOI https://doi.org/10.30525/978-9934-26-045-2-11

\title{
ЗАБЕЗПЕЧЕННЯ ІНКЛЮЗИВНОСТІ ВИБОРЧИХ ПРОЦЕСІВ
}

\author{
Редчиць О. С. \\ аспірантка кафедри глобалістики, євроінтеграції та управління \\ національною безпекою \\ Національної академії державного управління \\ при Президентові Украӥни \\ м. Київ, Украӥна
}

За даними Міністерства соціальної політики України, станом на 1 січня 2020 року чисельність осіб з інвалідністю в Україні становить 2,7 млн або 6,3 \% від загальної кількості населення країни [1].

3 них, близько 2,5 млн людей з інвалідністю $є$ громадянами та громадянками, які досягли 18 річного віку та можуть бути суб'єктами виборчого процесу та реалізовувати своє активне і пасивне виборче право.

В цілому, в світі понад мільярд людей, які мають різні форми інвалідності: фізичну (порушення, які впливають на мобільність, рух або тіло), сенсорну (порушення зору, слуху), психосоціальну (порушення сприйняття, поведінки, емоцій) чи інтелектуальну (порушення інтелектуального розвитку, які впливають на можливості вчитися на очікуваному рівні та вести повсякденне життя) і чисельність таких людей має тенденцію до зростання внаслідок старіння населення, пандемії COVID-19 та у результаті військових конфліктів.

У Всесвітній доповіді з інвалідності (2011 рік) визначено основні бар'єри, які перешкоджають повноцінній участі осіб з інвалідністю у суспільному житті, такі як:

відсутність доступності (фізичні бар'єри): значна кількість будинків, споруд (у тому числі місць загального користування), транспорту є недоступними для осіб з інвалідністю;

недосконала організація надання послуг: слабка координація організації надання послуг, недостатнє кадрове забезпечення та низький рівень професійної підготовки персоналу;

незадовільний стан інформації і комунікації: види інформації та методи комунікації повинні бути доступними і розробленими з використанням технологій, які враховують різні нозологічні групи інвалідності [2]. 
Концепція інклюзивності, тобто повного та ефективного залучення та включення до суспільства людей з інвалідністю означає, що суспільство як в публічному, так і в приватному вимірах організовано таким чином, що всі люди можуть повноцінно брати участь в його житті, люди 3 інвалідністю визнаються і цінуються як рівні учасники. Їхні потреби розуміються як невід'ємна частина соціальноекономічного порядку, а не як «особливі». Для забезпечення повного, інклюзивного включення людей з інвалідністю $є$ необхідним доступне, вільне від бар'єрів фізичне та соціальне середовище. Наприклад, люди з інвалідністю не виключаються із політичних виборчих процесів через відсутність інфраструктурної доступності місць для голосування та відсутності легких для розуміння матеріалів стосовно виборів в різних форматах.

Однак, інклюзивність виборчих процесів стосується не тільки людей з інвалідністю, а й маломобільних груп населення. До них відносяться вагітні жінки, люди з тимчасовими порушеннями здоров'я, дорослі з дітьми на візках, люди похилого віку. Реалізація виборчих прав для значної частини цих людей є суттєво ускладненою.

Заходи, що вживаються країнами Європейського Союзу для здійснення права людей з інвалідністю на участь у виборах в якості кандидатів, включають виявлення й усунення перешкод для фізичної доступності, розробку і здійснення мінімальних норм i керівних принципів щодо забезпечення доступу до громадських будівель, надання інформації у доступних форматах (наприклад, за допомогою абетки Брайля і в доступній і зрозумілій формі) в будівлях та інших об'єктах, відкритих для громадськості, а також заохочення і використання нових видів технологій, зокрема інформаційно-комунікаційних технологій, засобів та пристроїв забезпечення мобільності, а також асистивних технологій, придатних для людей з інвалідністю.

В свою чергу, Україна у 2009 році ратифікувала Конвенцію про права осіб з інвалідністю. Внаслідок чого, державою було взято зобов'язання вжити належних заходів щодо гарантування особам 3 інвалідністю участі в політичному та суспільному житті, зокрема шляхом забезпечення того, щоб процедури, приміщення та матеріали для голосування були підхожими, доступними та легкими для розуміння й використання [3].

На виконання вимог Конвенції постановою Кабінету Міністрів України від 01 серпня 2012 р. № 706 була затверджена Державна цільова програма «Національний план дій щодо реалізації Конвенції про права осіб з інвалідністю» на період до 2020 року». Програма 
спрямована на заохочення, захист і забезпечення повного й рівного здійснення особами 3 інвалідністю всіх прав людини та основоположних свобод в усіх сферах суспільного життя 3 урахуванням положень Конвенції, а також вжиття заходів щодо поважного ставлення до притаманної їм гідності [4].

Також, з метою забезпечення додержання та реалізації прав і свобод осіб 3 інвалідністю відповідно до вимог Конвенції про права осіб з інвалідністю було підписано Указ Президента України № 553/2016 «Про заходи, спрямовані на забезпечення додержання прав осіб 3 інвалідністю». У 2015 році Україна представила на розгляд Комітету ООН з прав осіб з інвалідністю Першу періодичну Доповідь про реалізацію положень Конвенції про права осіб з інвалідністю.

Крім того, Виборчим Кодексом України, що вступив в силу 1 січня 2020 року встановлено заборону будь-яких прямих чи непрямих привілеїв або обмежень виборчих прав громадян України за ознаками раси, кольору шкіри, політичних, релігійних та інших переконань, статі, етнічного та соціального походження, майнового стану, місця проживання, інвалідності та стану здоров'я, за мовними або іншими ознаками та визначено вимоги щодо процедур, приміщень та матеріалів для забезпечення безперешкодного доступу людей 3 інвалідністю та інших маломобільних груп населення для реалізації виборчих прав. Важливим є і те, що Виборчий Кодекс України визначає сприяння у наданні допомозі виборцю, який внаслідок інвалідності та/або стану здоров'я не може самостійно заповнити виборчий бюлетень чи опустити його у виборчу скриньку. Закріпленими є можливість присутності супроводжуючих осіб людей 3 інвалідністю як учасників засідань виборчої комісії, визначається порядок організації голосування виборців за місцем перебування. Також передбаченою є можливість оскарження дій/бездіяльності у зв'язку з незабезпеченням умов для доступу виборців з інвалідністю до виборчого процесу [5].

Проте, Виборчий Кодекс України не містить процедурних особливостей щодо людей 3 інвалідністю та маломобільних груп населення на всіх етапах виборчого процесу. Наразі відсутні альтернативні способи голосування.

В свою чергу, наприклад в країнах Свропейського Союзу поширеними способами голосування на виборах $\epsilon$ голосування поштою, його використовують 19 країн та голосування за місцем тимчасового перебування виборця - 18 країн. Електронне голосування на сьогодні проходить етап тестування. Такий спосіб голосування практикують у декількох країнах Європейського Союзу: Бельгія (для 
всіх видів виборів та референдумів), Болгарія (для національних виборів та виборів до Свропарламенту), Естонія (на всіх національних виборах, крім місцевих референдумів), Франція (на місцевому рівні), Ісландія та Норвегія (для місцевих референдумів).

Відповідно до Рекомендації $\mathrm{CM} / \operatorname{Rec}(2017) 5$ електронне голосування охоплює електронне подання голосів та електронний підрахунок бюлетенів. Електронне подання голосів передбачає як голосування на електронних машинах для голосування на виборчих дільницях, так і голосування через інтернет із неконтрольованого середовища [6].

Тому, альтернативні способи голосування можуть забезпечити в певній мірі реалізацію виборчих прав людей з інвалідністю та інших маломобільних груп населення.

Таким чином, Україна робить лише перші кроки до безперешкодності у доступі людей з інвалідністю та маломобільних громадян до виборчого процесу. Виборчий кодекс України визначив основні передумови та потребує доопрацювання та розробки підзаконних нормативних актів у сфері реалізації виборчих прав людей з інвалідністю через запровадження альтернативних способів голосування, участі людей з інвалідністю у виборах як кандидатів, членів виборчих комісій, офіційних спостерігачів тощо.

\section{Література:}

1. Інвалідність. Міністерство соціальної політики України. URL: https://www.msp.gov.ua/timeline/invalidnist.html (дата звернення 16.02.2021).

2. Всемирный доклад по инвалидности. Всемирная организация здравоохранения, 2011 г. URL: https://cutt.ly/vlhvaUS (дата звернення 15.02.2021).

3. Конвенція про права інвалідів: прийнята і проголош. резолюцією № 61/106 Генеральної асамблеї ООН від 13.12.2006 p. // База даних «Законодавство України». URL: https://zakon.rada.gov.ua/laws/show/ 995_g71\#Техt (дата звернення 16.02.2021).

4. Про затвердження Державної цільової програми «Національний план дій $з$ реалізації Конвенції про права осіб 3 інвалідністю» на період до 2020 року: Постанова Кабінету Міністрів України від 01.08.2012 p. № 706 // База даних «Законодавство України». URL: https://zakon.rada.gov.ua/laws/show/706-2012-\%D0\%BF\#Text (дата звернення 16.02.2021). 
5. Виборчий кодекс України. // База даних «Законодавство України». URL: https://zakon.rada.gov.ua/laws/show/396-20\#Text (дата звернення 16.02.2021).

6. Recommendation $\mathrm{CM} / \operatorname{Rec}(2017) 51$ of the Committee of Ministers to member States on standards for e-voting. Adopted by the Committee of Ministers on 14 June 2017 at the 1289th meeting of the Ministers' Deputies. URL: https://rm.coe.int/0900001680726f6f (дата звернення 14.02.2021).

DOI https://doi.org/10.30525/978-9934-26-045-2-12

\title{
ДЕЯКІ АСПЕКТИ ЗАСТОСУВАННЯ ПОНЯТЬ ЩДЕРЖАВНЕ УПРАВЛІННЯ» ТА «ПУБЛІЧНЕ УПРАВЛІННЯ І АДМІНІСТРУВАННЯ» В УКРАЇНІ
}

\author{
Сабурова Г. Б. \\ начальник відділу документування управлінської діяльності апарату \\ Полтавської обласної державної адміністращії \\ м. Полтава, Україна
}

Така галузь науки як «публічне управління і адміністрування» 3'явилась на терені інших наук в Україні порівняно недавно і посіла там гідне місце.

Передумовою iii виникнення та становлення був бурхливий розвиток новітніх інформаційних технологій, поступова інформатизація суспільства, прогресивний розвиток державної інформаційної політики, подальший розвиток демократичних засад громадянського суспільства, пов'язаний з процесами децентралізації, а також численні праці українських вчених та науковців.

Освітня галузь України не могла залишатись осторонь викликів часу. В багатьох закладах вищої освіти були створені кафедри публічного управління і адміністрування, на яких викладацьку та наукову діяльність 3 цього напрямку ведуть кандидати та доктори наук саме 3 державного управління. При деяких академіях, університетах та інститутах були відкриті аспірантури, які готують фахівців 3-го рівня вищої освіти за спеціальністю 281 - «Публічне управління і адміністрування» під керівництвом докторів наук саме 3 державного управління.

Слід відзначити також, що станом на 2019 рік для вищевказаної спеціальності спецкомісією МОН України начолі з проф. С.А.Чукут 